\title{
Differential Effects of Cyclosporin A and Tacrolimus on Magnesium Influx in Caco2 Cells
}

\author{
Elodie Gouadon ${ }^{1}$, Florence Lecerf ${ }^{1}$, Michèle German-Fattal ${ }^{1,2}$ \\ ${ }^{1}$ INSERM UMR-S 999, Labex LERMIT, University of Paris-Sud 11, Centre Chirurgical Marie-Lannelongue, 92350 Le \\ Plessis-Robinson, France. \\ ${ }^{2}$ University of Paris-Sud 11, Faculty of Pharmacy, 92290 Châtenay-Malabry, France.
}

Received, January 25, 2012; Revised, April 30, 2012; Accepted, May June 12, 2012; Published, June 13, 2012.

\begin{abstract}
PURPOSE: Hypomagnesemia with urinary magnesium (Mg) wasting is a well acknowledged side effect of cyclosporin A (CsA) and tacrolimus (FK506) treatments. TRPM6, TRPM7 and MagT1 are involved in the active transcellular Mg transport processes in intestine and kidney. Since $\mathrm{Mg}$ homeostasis is tightly controlled by the dynamic action of intestinal absorption of dietary $\mathrm{Mg}$ and renal excretion of Mg, we investigated whether CsA and FK506 in commercially available solutions for clinical use decrease the expression and the function of TRPM6, TRPM7 or MagT1 in the intestinal epithelial cell line Caco2. METHODS: Changes of intracellular free Mg concentrations were measured by Mag-fura-2 imaging in Mg-free medium after the addition of $1 \mathrm{mM} \mathrm{MgCl2.} \mathrm{TRPM6,} \mathrm{TRPM7} \mathrm{and} \mathrm{MagT1} \mathrm{were}$ evidenced in cells by immunofluorescence. Proteins and mRNAs were quantified after 18 hours of treatment with CsA or FK506 by western-blot and real-time RT-PCR analyses, respectively. RESULTS: TRPM6 and MagT1 were evidenced on all cell membranes, TRPM7 only on the inner membranes. CsA was responsible for a profound decrease in $\mathrm{Mg}^{2+}$ influx in intestinal epithelial cells, which may result in a decrease of intestinal Mg absorption, whereas FK506 was responsible for a marked increase in $\mathrm{Mg}^{2+}$ influx. Neither CsA nor FK506 altered TRPM6, TRPM7 or MagT1 mRNA levels or MagT1 protein level. CONCLUSIONS: In Caco 2 cells, $\mathrm{Mg}^{2+}$ influx was inhibited by CsA solutions whereas enhanced by FK506 solutions, without alteration of MagT1, TRPM6 and TRPM7 expression, leading to the conclusion that CsA and FK506 have opposite effects in the functional activity of the Mg transporters herein examined. In clinical use, FK506 should be preferred for patients at risk for hypomagnesemia.
\end{abstract}

This article is open to POST-PUBLICATION REVIEW. Registered readers (see "For Readers") may comment by clicking on ABSTRACT on the issue's contents page.

\section{INTRODUCTION}

Cyclosporin A (CsA) and tacrolimus (FK506) are potent immunosuppressants widely used to prevent organ allograft rejection and for patients with allergies and immune-mediated diseases. Both drugs inhibit the phosphatase calcineurin, but through different mechanisms (1). Hypomagnesemia with urinary magnesium $(\mathrm{Mg})$ wasting is a well acknowledged side effect of CsA and FK506 treatments (2-6). Severe Mg deficiency causes tetany, hypertension, seizures, and cardiac arrhythmia (7). $\mathrm{Mg}$ homeostasis is tightly controlled by the dynamic action of intestinal absorption of available dietary $\mathrm{Mg}$, exchange with bone, and renal excretion (8). TRPM6 (Transient Receptor Potential Melastatin) and TRPM7 are channel kinases involved in the active transcellular $\mathrm{Mg}$ transport processes in intestine and kidney. These ion channels have a permeation profile of magnesium $>$ calcium $(9$, 10). They have been associated with $\mathrm{Mg}^{2+}$ influx and homeostasis $(11,12)$. While TRPM6 is mainly restricted to the absorptive epithelial intestine and kidney where it regulates total body $\mathrm{Mg}$ levels, TRPM7 is ubiquitously expressed and may be more important in regulating intracellular $\mathrm{Mg}$ homeostasis and free intracellular levels of magnesium $\left(\left[\mathrm{Mg}^{2+}\right]_{\mathrm{i}}\right)(9,13-16)$. MagT1, a selective $\mathrm{Mg}^{2+}$ transport protein with very little permeability to other divalent cations, is ubiquitously expressed $(17,18)$. It is involved in maintaining intracellular $\mathrm{Mg}^{2+}$ levels (19).

The expression of TRPM6, the gatekeeper of the body's $\mathrm{Mg}$ balance, was shown to be regulated by extracellular $\mathrm{Mg}$ concentration, several hormones, and drug treatments, among which CsA and FK506, whereas its channel activity is modified by $\left[\mathrm{Mg}^{2+}\right]_{\mathrm{i}}$ and ATP $(20-22)$.

\footnotetext{
Corresponding Author: Michèle German-Fattal, INSERM UMR-S 999, Centre Chirurgical Marie-Lannelongue, 133 avenue de la Résistance, 92350 Le Plessis-Robinson, France; E-mail : michele.german@u-psud.fr
} 
CsA decreases TRPM6 expression and function in renal tubular epithelial cells, which could result in a decreased renal $\mathrm{Mg}$ reabsorption (23). However, we have previously shown that CsA treatment of mice induced moderate hypomagnesemia without urinary wasting or renal dysfunction, which could not be ameliorated by oral supplementation. Plasma Mg levels improved rapidly upon CsAtreatment cessation (24). So far, calcineurin inhibitors influence on MagT1 function and expression has not been investigated. Since $\mathrm{Mg}$ homeostasis is a balance of epithelial intestinal absorption and renal excretion, we investigated whether CsA and/or FK506 decrease the expression and/or function of TRPM6, TRPM7 or MagT1 in Caco2 cells taken as an epithelial intestinal cell model.

\section{MATERIALS AND METHODS}

\section{Materials}

Cyclosporin (Sandimmun ${ }^{\circledR} 50 \mathrm{mg} / \mathrm{mL}$ ) was from Novartis Pharma SAS (Rueil-malmaison, France), tacrolimus (Prograf ${ }^{\circledR} 5 \mathrm{mg} / \mathrm{mL}$ ) from Astellas Pharma (Le Vallois-Perret, France) and Cremophor $^{\mathbb{B}}$ EL from Sigma Aldrich (Saint Quentin Fallavier, France). The concentrations used were $1,10,100 \mu \mathrm{M}$, and $0.01,0.1,1 \mu \mathrm{M}$, for CsA and FK506, respectively. The vehicle for each concentration was prepared from stock solutions to mimic the vehicles of the commercially available drugs: $33 \%$ Cremophor $^{\circledR}$ EL and $67 \%$ ethanol, and $19.4 \%$ Cremophor $^{\circledR}$ EL and $80.6 \%$ ethanol, for CsA and FK506 vehicles, respectively. The stock solutions were further diluted in the same conditions as for CsA and FK506 stock solutions. Rabbit polyclonal antibodies to human TRPM6 and TRPM7 (LTRPC7) were from Osenses (Ozyme, SaintQuentin en Yvelines, France), goat polyclonal antibodies to human MagT1 and to human $\beta$-actin from Santa Cruz Biotechnology (Tebu-Bio, Le Perray-en-Yvelines), Alexa Fluor ${ }^{\circledR}$ (Alexa 488)conjugated goat anti-rabbit IgG and rabbit antigoat IgG from Invitrogen Molecular Probes (Interchim, Montluçon, France), horse-radish peroxidase-linked goat anti-rabbit IgG from Cell Signaling (Ozyme), horse-radish peroxidaselinked donkey anti-goat IgG from Santa Cruz Biotechnology. Mag-fura-2-AM ${ }^{\circledR}$ and pluronic F127 were from Invitrogen Molecular Probes.

\section{Cell culture}

Caco2 cells were grown in Dulbecco's modified Eagle's medium (D-MEM, Invitrogen-GIBCO) high glucose $(4,5 \mathrm{~g} / \mathrm{L})$ containing sodium pyruvate $(110 \mathrm{mg} / \mathrm{L})$ and $3.97 \mathrm{mM} \mathrm{L}$-glutamine, and supplemented with $1 \%$ non-essential amino acids (Invitrogen-GIBCO), 20\% fetal calf serum (Eurobio, Les Ulis, France), penicillin (100 $\mathrm{U} / \mathrm{mL})$ and streptomycin $(100 \mu \mathrm{g} / \mathrm{mL})$. After 7 days, cells are confluent as a monolayer. All experiments were performed after 7 days of culture. On the day before given experiments with CsA or FK506, cells culture in dishes or flasks were washed with warm media then provided with fresh media containing CsA or FK506.

\section{Immunofluorescence}

Cells were grown on glass slides (Lab-Tek ${ }^{\mathrm{TM}}$ chamber slide, 8 wells, Permanox ${ }^{\mathrm{TM}}$, Nunc, VWR International). After fixation with $4 \%$ paraformaldehyde in PBS for $30 \mathrm{~min}$, cells were washed 3 times in PBS. WGA (Wheat Germ Agglutinin) Alexa Fluor $^{\circledR} 594$ conjugate (Invitrogen), a plasma membrane marker, was applied at $5 \mu \mathrm{g} / \mathrm{ml}$ for $10 \mathrm{mins}$ at room temperature. Cells were washed 3 times in PBS. For TRPM6 and TRPM7, cells were permeabilized in $0.1 \%$ Triton $\mathrm{X}-100$ at $4{ }^{\circ} \mathrm{C}$ for 5 min. After a rinse in PBS, non specific binding sites were blocked by incubation in 10\% normal rabbit or goat IgG (R\&D Systems, Lille, France) for TRPM6/7 and MagT1, respectively, for $1 \mathrm{~h}$. Subsequently, cells were incubated with primary anti-TRPM6, anti-TRPM7 or anti-MagT1 antibody in a solution reducing background signal (Antibody diluent, Dako Real $^{\mathrm{TM}}$, Dako France, Trappes) at $4^{\circ} \mathrm{C}$ overnight. Then secondary Alexa Fluor $^{\circledR}$ antibody was applied for $30 \mathrm{~min}$. Negative control coverslips were processed following the same protocol, but normal goat or rabbit IgG (R\&D Systems) was applied instead of primary antibody to check for non specific binding. DAPI (SIGMA D8417, $0.001 \mu \mathrm{g} / \mathrm{mL}$ ) was applied for 15 min to counterstain nuclei in blue. After a brief rinse in PBS, coverslips were mounted on slides with Fluorescent Mounting reagent (Dako). Immunolabeled cells were visualized on LSM 700 confocal microscope (Carl Zeiss).

\section{Total Mg quantification}

Caco2 cells were grown in $25 \mathrm{~cm}^{2}$ flasks (500 000 cells $/ 5 \mathrm{~mL}$ ) and cultured for 6 days. The confluent cells were either untreated, or treated with CsA $(10 \mu \mathrm{M})$ or FK506 $(0.1 \mu \mathrm{M})$ for $24 \mathrm{~h}$. Cells were washed with PBS, trypsinized then homogenized in cold PBS. $2 \times 10^{6}$ cells were transferred to a microfuge tube and placed on ice, then sonicated in $100 \mu \mathrm{L}$ PBS for five pulses at a $40 \%$ duty cycle using an ultrasonic processor (VibraCellTM, Sonics and materials, Danbury, USA). After 
centrifugation for $10 \mathrm{~min}$ at $10000 \mathrm{rpm}$, the supernatant was collected and total $\mathrm{Mg}^{2+}$ concentration was measured using a xylidyl blue method by routine procedure in a clinical chemistry analyzer (AU400, Olympus, Rungis, France) at a wavelength of $520 \mathrm{~nm}$. Results were expressed in nmol/ $10^{6}$ cells.

\section{Measurement of intracellular free $\left[\mathrm{Mg}^{2+}\right]_{i}$ by Mag-fura-2 imaging}

$\left[\mathrm{Mg}^{2+}\right]_{\mathrm{i}}$ was determined using $\mathrm{Mg}^{2+}$-sensitive fluorescent dye Mag-fura-2-AM. On the experimental day, cells grown on glass bottom dishes (Fluorodish $^{\circledR}$, WPI, Aston, UK) were incubated in a Hanks balanced salt solution (HBSS, Invitrogen-GIBCO) without $\mathrm{Mg}^{2+}$, containing $10 \mathrm{mM}$ glucose and supplemented with $20 \mathrm{mM}$ Hepes/Tris (pH 7.4), $1.3 \mathrm{mM} \mathrm{CaCl}_{2}$, $2 \mu \mathrm{M}$ Mag-fura-2-AM and pluronic $\mathrm{F}-127$ $(0.02 \%, \mathrm{w} / \mathrm{v})$ at $37^{\circ} \mathrm{C}$ for $30 \mathrm{~min}$. The loaded cells were washed in the dye-free HBSS, then the changes in Mag-fura-2 fluorescence were monitored at 2-s intervals using a dedicated imaging station consisting of an inverted Olympus IX71 microscope (Olympus, Rungis, France), a monochromator (Polychrome V, TILL Photonics, Roper, Les Ulis, France), and a CDD camera (CoolSnap HQ, Photometrics, Roper). Standard image pairs of Mag-fura-2 fluorescence with excitation at $340 \mathrm{~nm}$ and $380 \mathrm{~nm}$ were acquired at the wavelength of emission of $510 \mathrm{~nm}$ with an exposure time of $100 \mathrm{~ms}$, using a UVApochromat 40x oil immersion objective (N.A. 1.35). Differential interference contrast (DIC) images were taken after each pair of fluorescence images. After substracting background, the fluorescence ratios $(340 / 380 \mathrm{~nm})$ in selected regions of interest were calculated off line. Both image acquisition and analysis were performed using the Metafluor ${ }^{\circledR}$ software (Molecular Devices, Roper). The $\left[\mathrm{Mg}^{2+}\right]_{\mathrm{i}}$ were calculated from the fluorescence ratios, using a dissociation constant (Kd) of $1.45 \mathrm{mM}$ for the Mag-fura$2 / \mathrm{Mg}^{2+}$ complex (25). The minimum (Rmin) and maximum (Rmax) ratios were determined using $20 \mu \mathrm{M}$ digitonin. The Rmax for Mag-fura-2 was determined by the addition of $50 \mathrm{mM} \mathrm{MgCl}$, and the Rmin was obtained by removal of the $\mathrm{Mg}^{2+}$ and the addition of $100 \mathrm{mM}$ EDTA (26). The change in $\left[\mathrm{Mg}^{2+}\right]_{\mathrm{i}}$ with time $\left(\mathrm{d}\left(\left[\mathrm{Mg}^{2+}\right]_{\mathrm{i}} / \mathrm{dt}\right)\right.$ was determined by linear regression analysis of the fluorescence ratio over the initial $600 \mathrm{~s}$ and expressed in $\mathrm{nmol} / \mathrm{s}$.
RNA quantification by real-time reversetranscription-polymerase chain reaction (RTPCR)

Total RNA was isolated from cell homogenates according to the Agilent Total RNA Isolation protocol (Agilent Technologies, Massy, France). Reverse transcription into cDNA with elimination of genomic DNA was performed using the QuantiTect $^{\circledR}$ Reverse Transcription protocol (Qiagen, Les Ulis, France). Real-time PCRs were performed using the SteponePlus ${ }^{\mathrm{TM}}$ Real-Time PCR System according to the TaqMan ${ }^{\circledR}$ Gene Expression Assays protocol (Applied Biosystems, Villebon-sur-Yvette, France) in 96-wells plates in a total volume of $20 \mu \mathrm{l}$. The TRPM6, TRPM7, MagT1 and $\beta$-actin primer pairs amplify fragments of $68,88,67$, and $171 \mathrm{bp}$, respectively. Relative gene expression was calculated using the delta-delta $\mathrm{Ct}$ method with normalization to $\beta$ actin (A.U.).

\section{Western blot analysis}

Caco2 were scraped into cold PBS and precipitated by centrifugation at $1,400 \mathrm{~g}$ for $5 \mathrm{~min}$ at $4^{\circ} \mathrm{C}$. Then the cells were lysed in a buffer containing $150 \mathrm{mM} \mathrm{NaCl}, 1 \mathrm{mM}$ EDTA, $1 \% \mathrm{NP}$ 40, $1 \mathrm{mM}$ phenylmethylsulfonyl fluoride, $1 \mathrm{mM}$ NaVO4, $1 \mathrm{mM} \mathrm{NaF}, 50 \mathrm{mM}$ Tris- $\mathrm{HCl}$ (pH 8.0), and the protease inhibitors leupeptine $10 \mu \mathrm{g} / \mathrm{ml}$ and aprotinine $20 \mu \mathrm{g} / \mathrm{ml}$. After sonication for $20 \mathrm{~s}$, the whole cell lysate contained plasma membrane, cytoplasm and nuclear fraction. Protein concentration was measured using the BC Assay kit (Interchim).

Protein samples $(25 \mu \mathrm{g})$ were heated for 2 min at $100^{\circ} \mathrm{C}$ in Laemmli sample buffer (BioRad, Marnes-La-Coquette, France) containing 5\% $\beta$-mercaptoethanol. The denaturated proteins were then separated by SDS-polyacrylamide gel electrophoresis using precast $4-15 \%$ gels (Miniprotean ${ }^{\circledR} \mathrm{TGX}^{\mathrm{TM}}$, Bio-Rad) in Tris-glycine-SDS running buffer (27). Proteins were subsequently blotted onto polyvinylidene fluoride membranes. After transfer, the membranes were blocked with a 5\% solution of non-fat dry milk in Tris-buffered solution ( $\mathrm{pH} 7.6$ ) containing $0.05 \%$ Tween 20 (TBS-T) for $1 \mathrm{~h}(28)$. Then membranes were incubated at $4^{\circ} \mathrm{C}$ with each primary antibody (anti-TRPM6, TRPM7, MagT1 or $\beta$-actin) overnight. After washing, membranes were incubated with the peroxydase-conjugated secondary IgGs for $1 \mathrm{~h}$. Finally, the blots were stained with Immun-Star ${ }^{\text {TM }}$ WesternC ${ }^{\text {TM }}$ Chemiluminescent kit (Roche, Meylan, France). The protein blots were analyzed in the Bio-Rad Molecular Imager Chemidoc ${ }^{\mathrm{TM}}$. The band densities 
were quantified with Image Lab 3.0 analysis software (Biorad) and then expressed relative to the value of control $\mathrm{Caco} 2$ cells after normalization to $\beta$-actin.

\section{STATISTICS}

Results were presented as mean \pm SEM. Differences between groups were analyzed by one-way analysis of variance, and individual comparisons were made using the parametric Tukey's multiple comparison test $\left(\mathrm{PRISM}^{\circledR} 5\right.$ software, GraphPad, San Diego, USA). Significant differences were assumed at $\mathrm{p}<0.05$.

\section{RESULTS}

Since in clinical use, CsA and FK506 may be formulated with various vehicles (solution for injection or tablets), in this study we compared the effects of the two immunosuppressant molecules to their corresponding vehicle.

\section{Cell evidence of TRPM6, TRPM7 and MagT1}

Immunocytofluorescence showed that TRPM6, TRPM7 and MagT1 are expressed in the cell membranes of Caco 2 cells after 7 days of culture (Figure 1). However, TRPM7 is weakly expressed and only on the inner membranes.
A

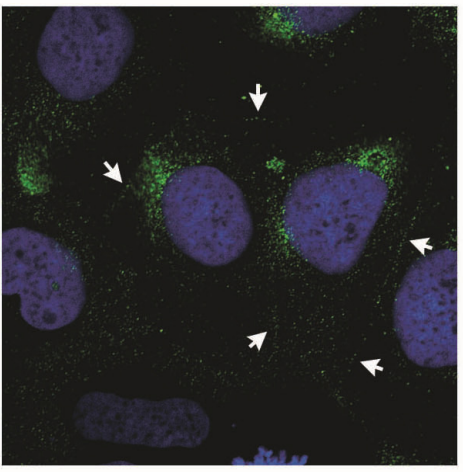

B

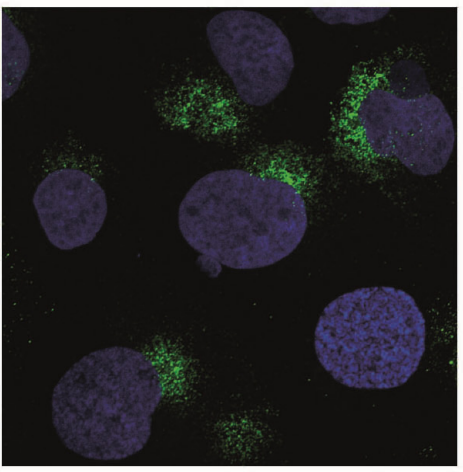

C

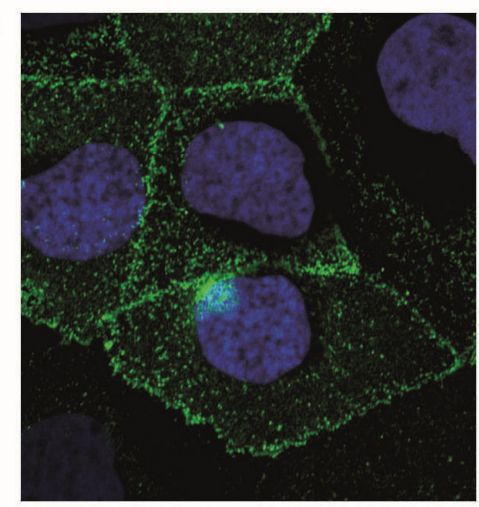

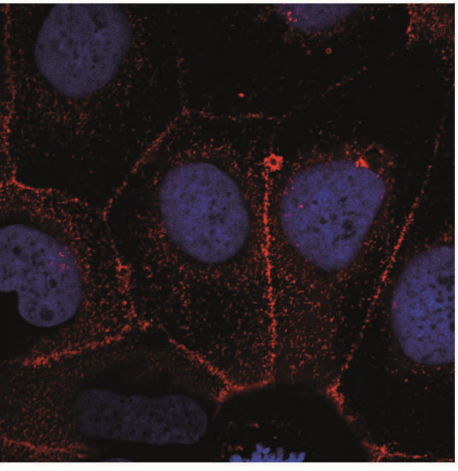
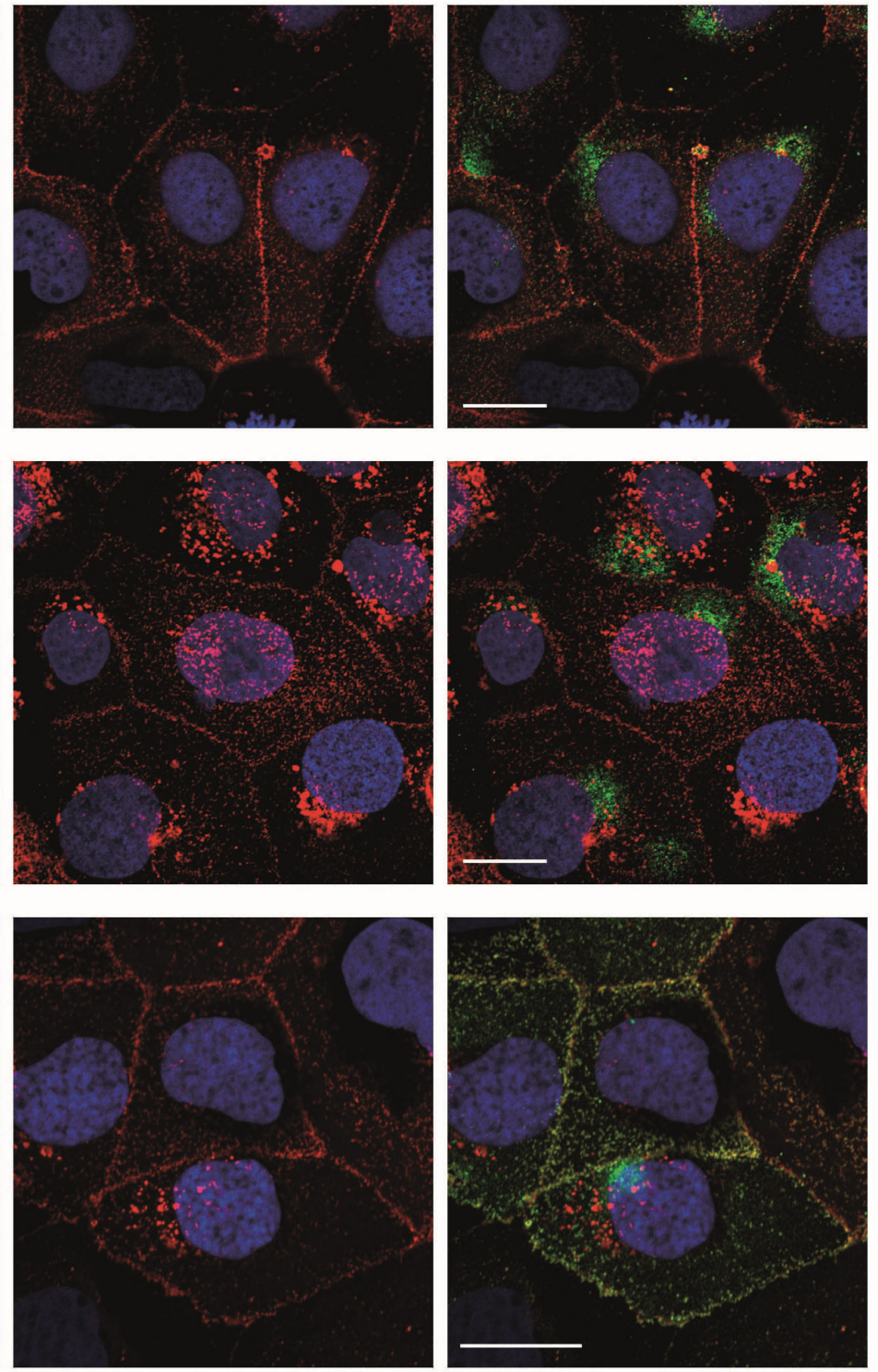

Figure 1. Cellular localization of magnesium transporters in Caco2 cells after 7 days of culture. TRPM6 (A), TRPM7 (B) and MagT1 (C) are labeled in green while plasma membrane (WGA) is labeled in red. Arrowheads point to TRPM6 expression on the plasma membrane. Scale bars, $20 \mu \mathrm{m}$. 
Effects of CsA and FK506 on the total $\mathrm{Mg}^{2+}$ concentration in Caco2 cells

The mean $\mathrm{Mg}^{2+}$ concentration in $\mathrm{Caco} 2$ cells was $18.25 \pm 0.14 \mathrm{nmol} / 10^{6}$ cells $(0.36 \pm 0.003$ $\mathrm{mmol} / \mathrm{L})(\mathrm{n}=6)$. Treatments with $10 \mu \mathrm{M}$ CsA or $0.1 \mu \mathrm{M}$ FK506, the intermediate doses, did not significantly alter intracellular $\mathrm{Mg}^{2+}$ concentrations compared to control cells (ns). At these doses, the CsA solution induced a significant diminution of intracellular $\mathrm{Mg}^{2+}$ concentration compared to the vehicle $(12.83 \pm$ $1.36 \mathrm{nmol} / 10^{6}$ cells and $22.50 \pm 3.33 \mathrm{nmol} / 10^{6}$ cells, respectively, $\mathrm{p}<0.05$ ) whereas the FK506 solution had no effect compared to the vehicle $\left(25.67 \pm 2.24 \mathrm{nmol} / 10^{6}\right.$ cells and $22.83 \pm 1.76$ $\mathrm{nmol} / 10^{6}$ cells, respectively, ns).

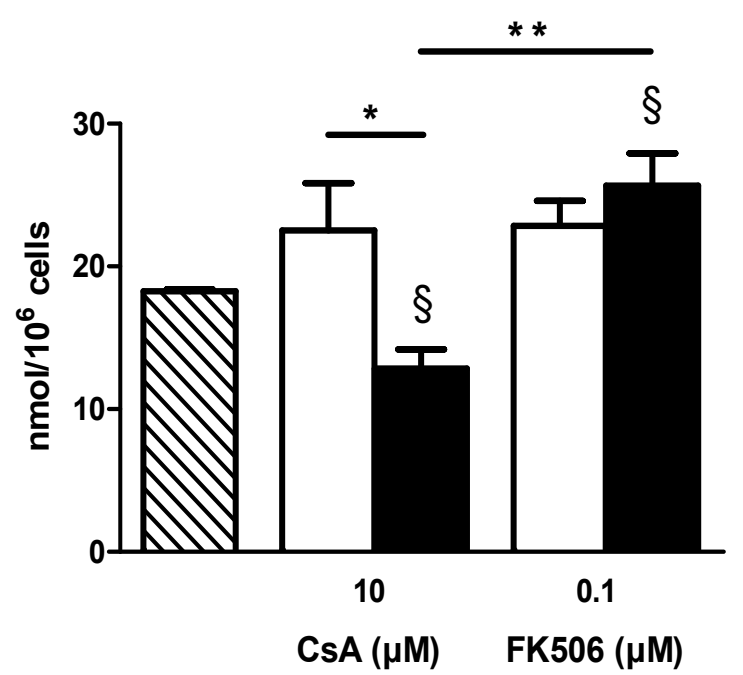

Figure 2. Effects of intermediate concentrations of CsA and FK506 on the total magnesium concentration in Caco 2 cells. The total $\mathrm{Mg}^{2+}$ concentration in Caco2 cells was quantified without treatment (hatched bar) or after $24 \mathrm{~h}$ of treatment with CsA $10 \mu \mathrm{M}$ or FK506 0.1 $\mu \mathrm{M}$ (black bars) or their respective vehicle (white bars). Results were expressed in nmol $/ 10^{6}$ cells. * $\mathrm{p}<0.05 ; * * \mathrm{p}<0.01 ; \S \mathrm{ns}$ compared to the control without treatment. $\mathrm{n}=3$.

\section{Differential effects of CsA and FK506 on $\left[\mathrm{Mg}^{2+}\right]_{i}$ elevation}

In Mg-free conditions, the addition of 1, 2.5, and $5 \mathrm{mM} \mathrm{MgCl}_{2}$ caused a dose-dependent elevation of $\left[\mathrm{Mg}^{2+}\right]_{\mathrm{i}}$ (Figure 3). In given experiments, cells were pretreated with $10 \mu \mathrm{M}$ of the TRPMinhibitor ruthenium red (RR) or with nitrendipine, an organic blocker of L-type $\mathrm{Ca}^{2+}$ channel for 10 min before adding $\mathrm{MgCl}_{2}$. Nitrendipine was shown to be an effective inhibitor of $\mathrm{Mg}^{2+}$ entry in MagT1 expressed oocytes and renal epithelial cells $(18,29)$. The elevation of $\left[\mathrm{Mg}^{2+}\right]_{\mathrm{i}}$ caused by the addition of $1 \mathrm{mM} \mathrm{MgCl}_{2}$ was significantly inhibited by RR or nitrendipine $(p<0.001)$, indicating that it reflects a $\mathrm{Mg}^{2+}$ influx from the extracellular compartment driven by the TRPM and MagT1 transporters (Figure 3). Therefore, a concentration of $1 \mathrm{mM} \mathrm{MgCl} 2$ was used in all the experiments.

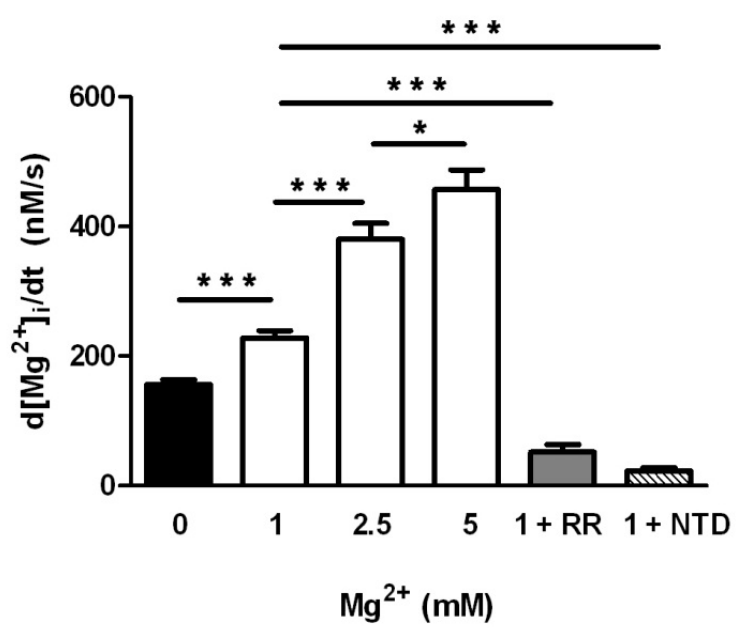

Figure 3. Magnesium influx in $\mathrm{Caco} 2$ cells placed in a glass dish in the absence of magnesium. After addition of $0,1,2.5$ or $5 \mathrm{mM} \mathrm{MgCl}$ to the bath solution, the increase in $\left[\mathrm{Mg}^{2+}\right]_{\mathrm{i}}$ per $\mathrm{s}$ for $600 \mathrm{~s}$ was calculated. Cells were pretreated with $10 \mu \mathrm{M}$ ruthenium red (RR) or nitrendipine (NTD) for $10 \mathrm{~min}$ before adding $1 \mathrm{mM}$ $\mathrm{MgCl}_{2}$ in the bath solution. Results were expressed in $\mathrm{nM} / \mathrm{s}$. * $\mathrm{p}<0.05 ; * * * \mathrm{p}<0.001 . \mathrm{n}=6$ dishes, 70 cells analyzed.

The DIC images of the cells showed that at the highest concentrations $(100 \mu \mathrm{M}$ CsA and $1 \mu \mathrm{M}$ FK506) the aspect was altered in a number of cells (blebbing and vacuolization) for both the immunosuppressant solutions and the vehicles. The CsA vehicule induced a significant and similar elevation of $\mathrm{Mg}^{2+}$ influx at the three concentrations $(\mathrm{p}<0.001$ versus untreated-cells $)$ (Figure 4A). CsA significantly inhibited the elevation of $\left[\mathrm{Mg}^{2+}\right]_{\mathrm{i}}$ induced by the vehicle $(p<0.0001)$ in a dose-dependent manner, which resulted in an apparent absence of effect on $\mathrm{Mg}^{2+}$ influx in $\mathrm{Caco} 2$ cells.

By contrast, FK506 vehicle induced a significant and similar reduction of $\mathrm{Mg}^{2+}$ influx at the three concentrations $(\mathrm{p}<0.001$ versus untreated cells) (Figure 4B). FK506 significantly enhanced $\left[\mathrm{Mg}^{2+}\right]_{\mathrm{i}}$ compared to the vehicle $(p<0.0001)$, which resulted in a significantly enhance of $\left[\mathrm{Mg}^{2+}\right]_{\mathrm{i}}$ at 0.1 and $1 \mu \mathrm{M}$ compared to untreated cells. 

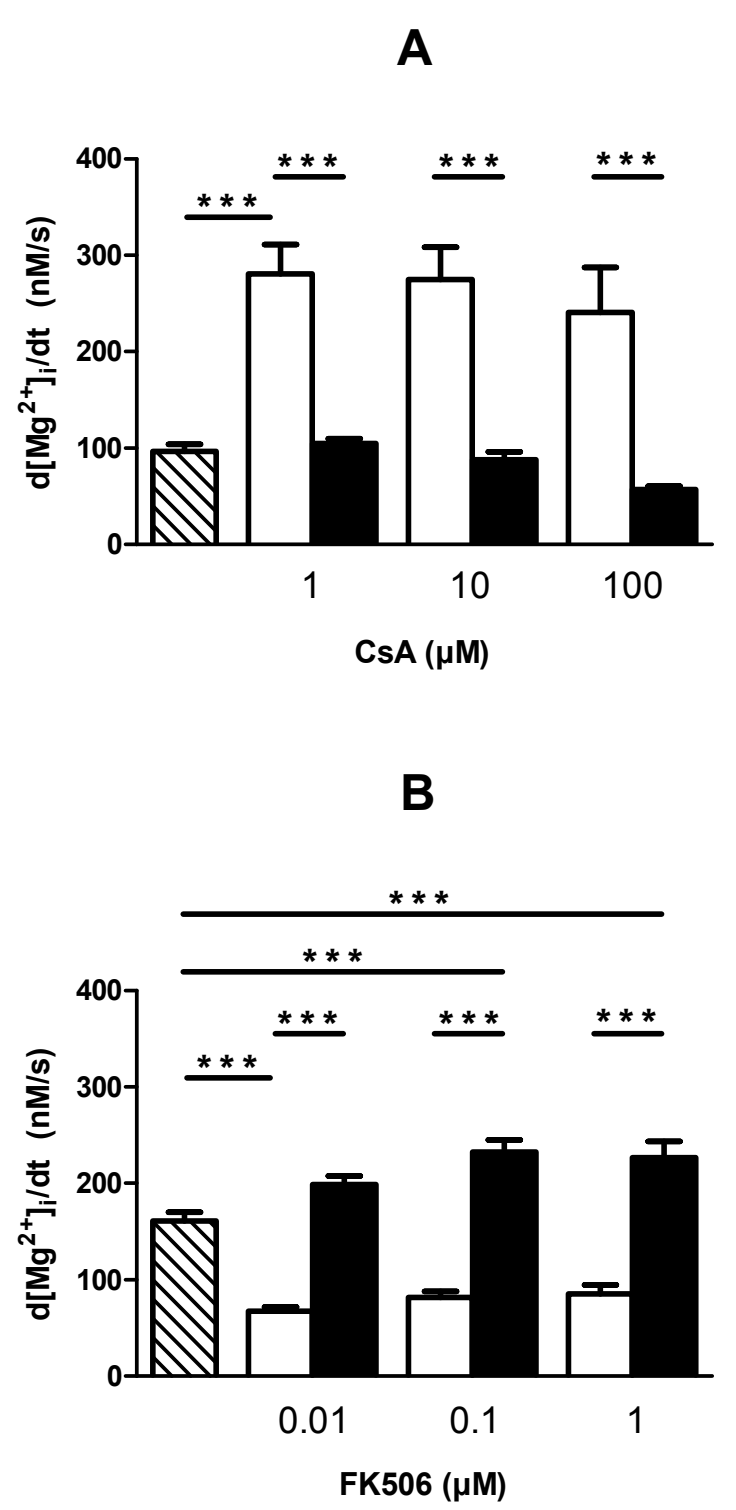

Figure 4. Magnesium influx in $\mathrm{Caco} 2$ cells after 18 hours of treatment with CsA (A, black bars) or FK506 (B, black bars) or with the corresponding vehicle (open bars). After addition of $1 \mathrm{mM} \mathrm{MgCl}_{2}$ to the bath solution, the increase in $\left[\mathrm{Mg}^{2+}\right]_{\mathrm{i}}$ per $\mathrm{s}$ for $600 \mathrm{~s}$ was calculated. Hatched bars: control cells. Results were expressed in $\mathrm{nM} / \mathrm{s}$. ${ }^{*} \mathrm{p}<0.001 . \mathrm{n}=6$ dishes, 70 cells analyzed.

\section{Effects of CsA and FK506 on TRPM6, TRPM7 and MagT1 expression}

RT-PCR showed that the only effect of the CsA vehicle was a dramatic decrease in TRPM6 mRNA level at the dose of $100 \mu \mathrm{M}$. (Figure 5A, $\mathrm{C}$ and $\mathrm{E})$. CsA at $100 \mu \mathrm{M}$ significantly increased MagT1 mRNA level compared with both untreated cells and vehicle $(p<0.001)$ (Figure 5A). At the same dose, CsA significantly decreased
TRPM6 mRNA level $(\mathrm{p}<0.001$ versus untreated cells) but similarly to the vehicle (Figure 5C).

By contrast, FK506 vehicle did not significantly alter MagT1, TRPM6 and TRPM7 mRNA levels (Figure 5B, D and F). FK506 at $0.01 \mu \mathrm{M}$ significantly enhanced MagT $1 \mathrm{mRNA}$ level $(p<0.001$ versus untreated cells $)$ but similarly to the vehicle (Figure 5B). FK506 did not significantly alter TRPM6 mRNA level whatever the dose was (Figure 5D). TRPM7 expression was not affected by the drugs (Figure $5 \mathrm{E}$ and $\mathrm{F})$.

Western-blot analysis of TRPM6 and TRPM7 proteins could not be performed since they were very weakly expressed in Caco 2 cells after 7 days of culture. By contrast, MagT1 was highly expressed and neither CsA nor FK506 altered its expression (Figure 6).

\section{DISCUSSION}

Hypomagnesemia, a frequent side-effect of calcineurin inhibitors, has been ascribed to an inhibition of renal tubular magnesium reabsorption, due to a decreased expression of TRPM6 $(5,23)$. In contrast to CsA, FK506 was shown to induce only a moderate and transient hypomagnesemia (30). In the present study, we demonstrate that those two calcineurin inhibitors display opposite effects on $\mathrm{Mg}^{2+}$ influx. So far, TRPM6 is the best known component mediating transepithelial $\mathrm{Mg}^{2+}$ transport, but TRPM7 and MagT1 might be involved in renal transepithelial $\mathrm{Mg}^{2+}$ transport (31). However, the disturbance of magnesium homeostasis may involve a decrease of intestinal absorption. Therefore, we investigated the effects of CsA and FK506 on the Mg transporters MagT1, TRPM6 and TRPM7 in intestinal epithelial cells. So far, these transporters have been widely investigated in kidney cells, and also in rumen and intestinal cells $(13-16,18,32)$. The selective Mg-transporter MagT1 is a $38 \mathrm{kDa}$ protein that is widely expressed among tissues, mainly colon and intestine, and in all cell membranes including endoplasmic reticulum, early and late endosomes or apical and basolateral plasma membrane fractions (18). It is upregulated by extracellular $\mathrm{Mg}^{2+}$ (32). In the present study, we used the Caco2 cell line since colon is one of the $\mathrm{Mg}^{2+}$-absorptive epithelia. These cells expressed both TRPM6 and TRPM7 at low levels, and MagT1 at a high level on plasma membranes. Therefore MagT1 might, in part, be responsible for intestinal Mg absorption. 


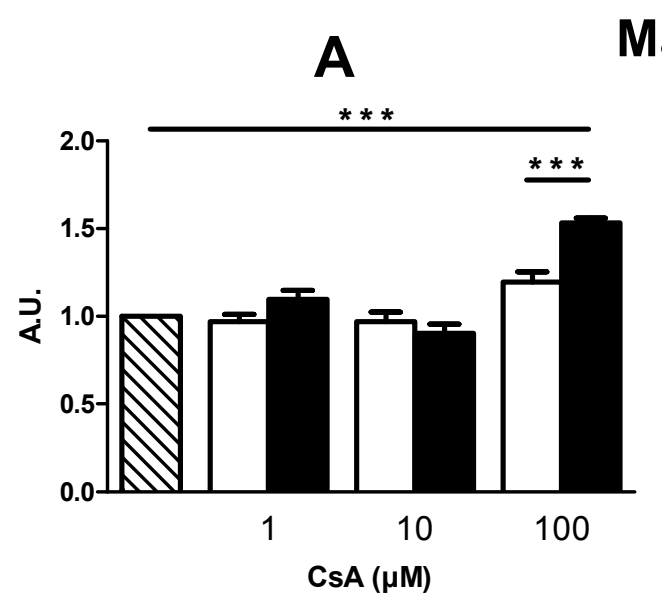

B
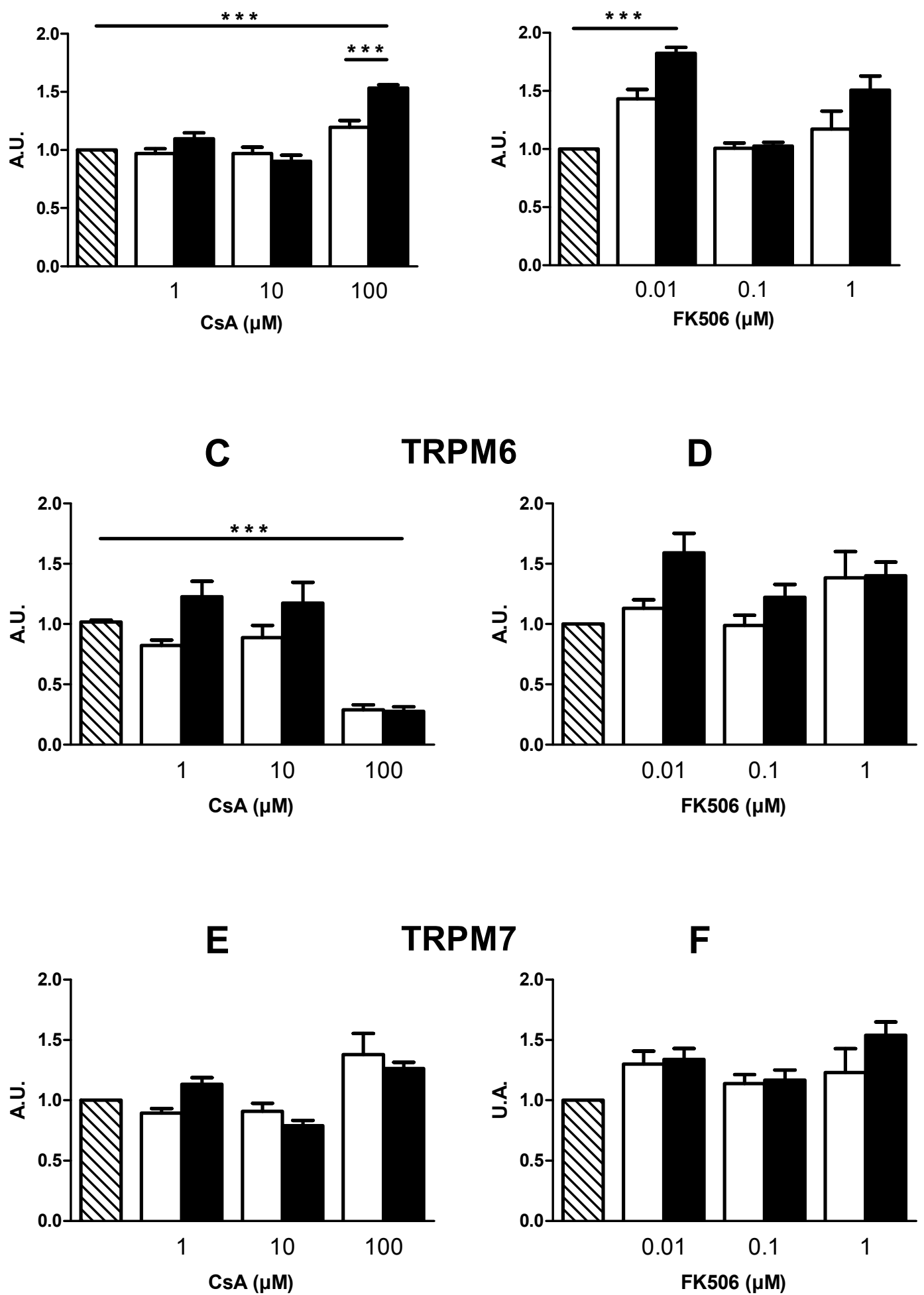

F

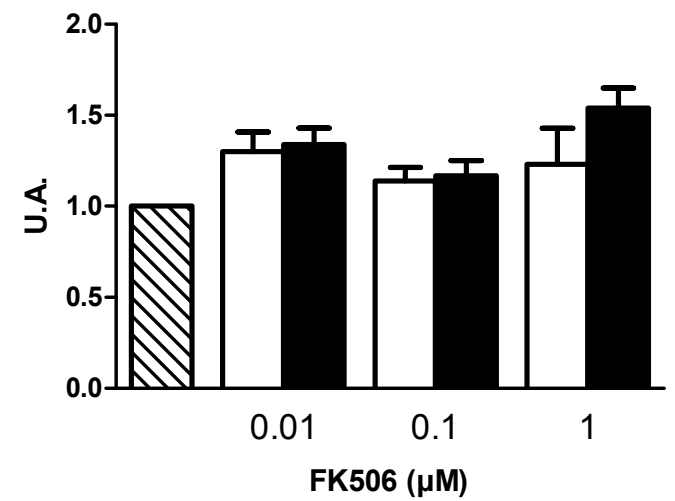

Figure 5. Effect of CsA (left blocks) and FK506 (right blocks) on MagT1 (A and B), TRPM6 (C and D) and TRPM7 (E and F) mRNA expression in Caco2 cells by real-time RT-PCR, after 18 hours of treatment with CsA or FK506 (black bars) or with the corresponding vehicle (open bars). Hatched bars: control cells. Results were expressed in arbitrary units (A.U.) after normalization to $\beta$-actin. ${ }^{* * *} \mathrm{p}<0.001 . \mathrm{n}=6$. 


\section{A}
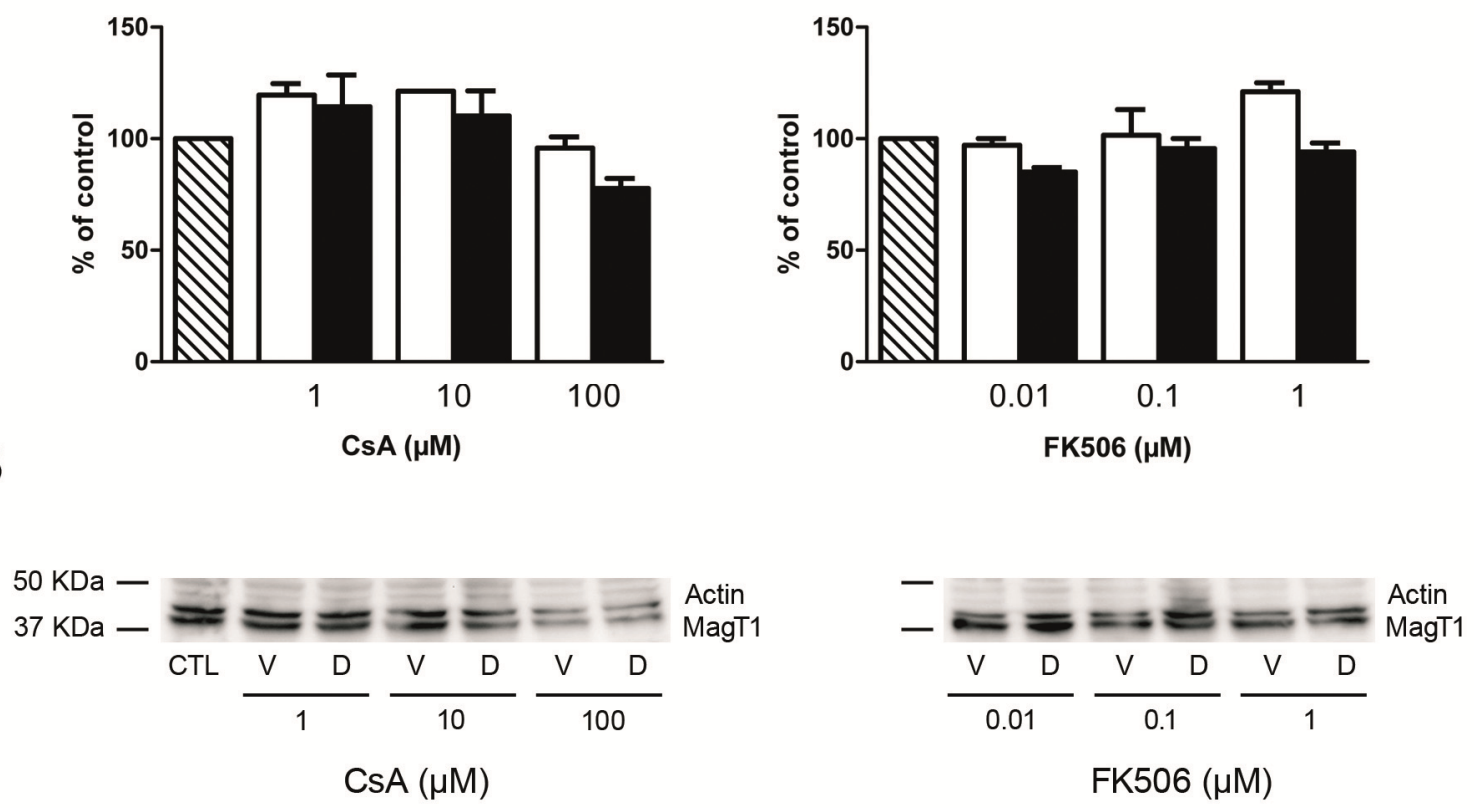

Figure 6. Effect of CsA (left blocks) and FK506 (right blocks) on MagT1 protein levels in Caco2 cells by westernblotting, after 18 hours of treatment with the drugs CsA or FK506 (black bars or D) or with the corresponding vehicle (open bars or V). A. Cell lysates were immunoblotted with anti-MagT1 or actin antibody. B. The band densities were expressed relative to the control value after normalization to $\beta$-actin. Hatched bars: control cells. $n=6$.

Intracellular free $\mathrm{Mg}^{2+}$ concentrations measured in Caco2 cells were in the reported 0.25 - $1 \mathrm{mM}$ range of mammalian cells $(33,34)$. The addition of $\mathrm{MgCl}_{2}$ caused an elevation of $\left[\mathrm{Mg}^{2+}\right]_{\mathrm{i}}$ in $\mathrm{Caco} 2$ cells under $\mathrm{Mg}$-free conditions in a dose-dependent manner, showing that $\mathrm{Mg}$ transport is dependent on the transmembrane concentration gradient.

Both $\mathrm{RR}$ and nitrendipine inhibited $\mathrm{Mg}^{2+}$ influx in Caco2 cells. The influx of $\mathrm{Mg}^{2+}$ mediated by TRPM6 and TRPM7 is inhibited by $\mathrm{RR}$, a potent blocker of inward monovalent currents while leaving outward currents unaltered, probably through a competition between $\mathrm{Mg}^{2+}$ for binding sites within the channel pore (9). Our findings support the notions that $\mathrm{Mg}^{2+}$ entry in Caco 2 cells is via channel-like proteins and that both TRPMs and MagT1 may be involved.

We compared the effects of the immunosuppressant molecules to those of their vehicle to evaluate the intrinsic effect of the molecules since the vehicles vary with the pharmaceutical formulation. Therefore, in clinical use, the effect of the treatment on $\mathrm{Mg}^{2+}$ absorption is expected to be at least in part dependent on the drug formulation. CsA, which is usually used in in vitro experimental designs in the range of 1 to $100 \mu \mathrm{M}$, induced a significant but not complete decrease of $\left[\mathrm{Mg}^{2+}\right]_{\mathrm{i}}$ in Caco2 cells compared to the vehicle and this vehicle induced a dramatic elevation of $\left[\mathrm{Mg}^{2+}\right]_{\mathrm{i}}$. By contrast, FK506 in the range of 0.1 to $1 \mu \mathrm{M}$ induced a dramatic elevation of $\left[\mathrm{Mg}^{2+}\right]_{\mathrm{i}}$ compared to both vehicle-treated and control cells. Contrarily to CsA, FK506 vehicle induced a dramatic decrease of $\left[\mathrm{Mg}^{2+}\right]_{\mathrm{i}}$.

These findings support the notion that CsA by itself (compared to the vehicle) is responsible for a profound decrease in $\mathrm{Mg}^{2+}$ influx in intestinal epithelial cells, which may result in a decrease of intestinal $\mathrm{Mg}$ absorption, whereas FK506 by itself (compared to the vehicle) is responsible for a marked increase in $\mathrm{Mg}^{2+}$ influx. Moreover, they emphasize the role of the vehicle in the overall pharmacological efficacy and side effects of these drugs.

The mRNAs of MagT1, TRPM6 and TRPM7 were expressed in the Caco2 cells, but only the MagT1 protein was highly expressed. Indeed, the expression of $\mathrm{Mg}$ transporters varies with the tissue, the cell type and the step of the cell cycle. Therefore, we could not investigate the effect of the drugs on TRPM6 and TRPM7 protein expression. By contrast with the modifications exhibited in $\mathrm{Mg}^{2+}$ influx, no decrease of TRPM6, TRPM7 or MagT1 mRNA levels and of MagT1 protein level was observed with CsA, and no 
significant increase of the mRNA and MagT1 protein level with FK506. It is worthy to note that the highest concentration of CsA vehicle induced damages in Caco2 cells and a dramatic decrease of TRPM6 mRNA level without affecting TRPM7 and MagT1 mRNAs. However, TRPM6 expression was shown to be decreased by CsA in normal rat kidney cells, but TRPM7 expression was not (23). We therefore hypothesize that both CsA and FK506 alter the channel function but not the mRNAs and proteins of those $\mathrm{Mg}$ transporters, unless other non-identified transporters are affected by these drugs.

In summary, in Caco2 cells, $\mathrm{Mg}^{2+}$ influx was inhibited by the CsA solution for clinical use whereas enhanced by FK506 solution, without alteration of MagT1, TRPM6 and TRPM7 expressions. Further studies are necessary to point out other $\mathrm{Mg}$ transporters involved in $\mathrm{Mg}^{2+}$ influx in intestinal epithelial cell, hence in intestinal $\mathrm{Mg}$ absorption. In clinical use, FK506 should be preferred for patients at risk for hypomagnesemia. Moreover, different formulations for the same calcineurin inhibitors may have different effects on Magnesium homeostasis.

\section{ACKNOWLEDGMENTS}

Elodie Gouadon was supported by a grant from "Région Ile-de-France". This work has benefited from the facilities and expertise of the "Plateforme d'imagerie cellulaire "of the Inserm Unit 999 at the Centre Chirurgical Marie Lannelongue.

\section{REFERENCES}

1. Liu J., Farmer J.D., Lane W.S., Friedman J., Weissman I., and Schreiber S.L. Calcineurin is a common target of cyclophilin-cyclosporin A and FKBP-FK506 complexes. Cell. 66:807-815 1991.

2. Barton C.H., Vaziri N.D., Martin D.C., Choi S., and Alikhani S. Hypomagnesemia and renal magnesium wasting in renal transplant recipients receiving cyclosporine. Am J Med. 83:693-699 1987.

3. McDiarmid S.V., Colonna J.O., 2nd, Shaked A., Ament M.E., and Busuttil R.W. A comparison of renal function in cyclosporine- and FK-506-treated patients after primary orthotopic liver transplantation. Transplantation. 56:847-853 1993.

4. Shihab F.S., Bennett W.M., Tanner A.M., and Andoh T.F. Mechanism of fibrosis in experimental tacrolimus nephrotoxicity. Transplantation. 64:1829-1837 1997.

5. Aisa Y., Mori T., Nakazato T., Shimizu T., Yamazaki R., Ikeda Y., and Okamoto S. Effects of immunosuppressive agents on magnesium metabolism early after allogeneic hematopoietic stem cell transplantation. Transplantation. 80:1046-1050 2005.

6. Jeon S.H., Kim S.J., Kim J.S., and Kang H.S. Immunosuppressant FK506 decreases the intracellular magnesium in the human osteoblast cell by inhibiting the ERK1/2 pathway. Life Sci. 84:23-27 2009.

7. Agus Z.S. Hypomagnesemia. J Am Soc Nephrol. 10:1616-1622 1999.

8. Quamme G.A., Schlingmann K.P., and Konrad M. Mechanisms and disorders of magnesium metabolism. In Hebert\&Alpern (ed.), The Kidney: Physiology the and Pathophysiology, Elsevier, San Diego, 2007, pp. 1747-1768.

9. Voets T., Nilius B., Hoefs S., van der Kemp A.W., Droogmans G., Bindels R.J., and Hoenderop J.G. TRPM6 forms the Mg2+ influx channel involved in intestinal and renal $\mathrm{Mg} 2+$ absorption. J Biol Chem. 279:19-25 2004.

10. Monteilh-Zoller M.K., Hermosura M.C., Nadler M.J., Scharenberg A.M., Penner R., and Fleig A. TRPM7 provides an ion channel mechanism for cellular entry of trace metal ions. J Gen Physiol. 121:49-60 2003.

11. Guther T., Vormann J., and Forster R. Regulation of intracellular magnesium by $\mathrm{Mg} 2+$ efflux. Biochem Biophys Res Commun. 119:124-131 1984.

12. Runnels L.W., Yue L., and Clapham D.E. TRPPLIK, a bifunctional protein with kinase and ion channel activities. Science. 291:1043-1047 2001.

13. Li M., Jiang J., and Yue L. Functional characterization of homo- and heteromeric channel kinases TRPM6 and TRPM7. J Gen Physiol. 127:525-537 2006.

14. Schlingmann K.P., Waldegger S., Konrad M., Chubanov V., and Gudermann T. TRPM6 and TRPM7-Gatekeepers of human magnesium metabolism. Biochim Biophys Acta. 1772:8138212007.

15. Touyz R.M. Transient receptor potential melastatin 6 and 7 channels, magnesium transport, and vascular biology: implications in hypertension. Am J Physiol Heart Circ Physiol. 294:H1103-1118 2008.

16. Quamme G.A. Recent developments in intestinal magnesium absorption. Curr Opin Gastroenterol. 24:230-235 2008.

17. Zhou H. and Clapham D.E. Mammalian MagT1 and TUSC3 are required for cellular magnesium uptake and vertebrate embryonic development. Proc Natl Acad Sci U S A. 106:15750-15755 2009.

18. Goytain A. and Quamme G.A. Identification and characterization of a novel mammalian $\mathrm{Mg} 2+$ transporter with channel-like properties. BMC Genomics. 6:48 2005.

19. Quamme G.A. Molecular identification of ancient and modern mammalian magnesium transporters. Am J Physiol Cell Physiol. 298:C407-429 2010. 
20. Groenestege W.M., Hoenderop J.G., van den Heuvel L., Knoers N., and Bindels R.J. The epithelial $\mathrm{Mg} 2+$ channel transient receptor potential melastatin 6 is regulated by dietary $\mathrm{Mg} 2+$ content and estrogens. J Am Soc Nephrol. 17:1035-1043 2006.

21. Rondon L.J., Groenestege W.M., Rayssiguier Y., and Mazur A. Relationship between low magnesium status and TRPM6 expression in the kidney and large intestine. Am J Physiol Regul Integr Comp Physiol. 294:R2001-2007 2008.

22. van der Wijst J., Hoenderop J.G., and Bindels R.J. Epithelial Mg2+ channel TRPM6: insight into the molecular regulation. Magnes Res. 22:127-132 2009.

23. Ikari A., Okude C., Sawada H., Takahashi T., Sugatani J., and Miwa M. Down-regulation of TRPM6-mediated magnesium influx by cyclosporin A. Naunyn Schmiedebergs Arch Pharmacol. 377:333-343 2008.

24. Sabbagh F., El Tawil Z., Lecerf F., Hulin A., Maurois P., Dartevelle P., Bac P., and GermanFattal M. Impact of cyclosporine A on magnesium homeostasis: clinical observation in lung transplant recipients and experimental study in mice. Transplantation. 86:436-444 2008.

25. Grynkiewicz G., Poenie M., and Tsien R.Y. A new generation of $\mathrm{Ca} 2+$ indicators with greatly improved fluorescence properties. J Biol Chem. 260:3440-3450 1985.

26. Kim S.J., Kang H.S., Jeong C.W., Park S.Y., Kim I.S., Kim N.S., Kim S.Z., Kwak Y.G., Kim J.S., and Quamme G.A. Immunosuppressants inhibit hormone-stimulated $\mathrm{Mg} 2+$ uptake in mouse distal convoluted tubule cells. Biochem Biophys Res Commun. 341:742-748 2006.
27. Ikari A., Nakajima K., Kawano K., and Suketa Y. Polyvalent cation-sensing mechanism increased $\mathrm{Na}(+)$-independent $\mathrm{Mg}(2+)$ transport in renal epithelial cells. Biochem Biophys Res Commun. 287:671-674 2001.

28. Wolf F.I., Trapani V., Simonacci M., Mastrototaro L., Cittadini A., and Schweigel M. Modulation of TRPM6 and $\mathrm{Na}(+) / \mathrm{Mg}(2+)$ exchange in mammary epithelial cells in response to variations of magnesium availability. J Cell Physiol. 222:3743812010.

29. Dai L.J., Ritchie G., Kerstan D., Kang H.S., Cole D.E., and Quamme G.A. Magnesium transport in the renal distal convoluted tubule. Physiol Rev. 81:51-84 2001.

30. Hulin A., Lamrani L., Sabbagh F., Tallet A., Lecerf F., Bac P., and German-Fattal M. Magnesium-deficiency does not alter calcineurin inhibitors activity in mice. Transplant immunology. 26:55-61 2012.

31. Ferre S., Hoenderop J.G., and Bindels R.J. Insight into renal $\mathrm{Mg} 2+$ transporters. Curr Opin Nephrol Hypertens. 20:169-176 2011.

32. Schweigel M., Kolisek M., Nikolic Z., and Kuzinski J. Expression and functional activity of the $\mathrm{Na} / \mathrm{Mg}$ exchanger, TRPM7 and MagT1 are changed to regulate $\mathrm{Mg}$ homeostasis and transport in rumen epithelial cells. Magnes Res. 21:118-123 2008.

33. Quamme G.A. Renal magnesium handling: new insights in understanding old problems. Kidney Int. 52:1180-1195 1997.

34. Grubbs R.D. Intracellular magnesium and magnesium buffering. Biometals. 15:251-259 2002. 